\title{
Lineage-specific duplications of NBS-LRR genes occurring before the divergence of six Fragaria species
}

\author{
Yan Zhong ${ }^{1 *}$, Xiaohui Zhang ${ }^{2}$ and Zong-Ming Cheng ${ }^{1,3^{*}}$
}

\begin{abstract}
Background: Plant disease resistance $(R)$ genes are evolving rapidly and play a critical role in the innate immune system of plants. The nucleotide binding sites-leucine rich repeat (NBS-LRR) genes are one of the largest classes in plant $R$ genes. Previous studies have focused on the NBS-LRR genes from one or several species of different genera, and the sequenced genomes of the genus Fragaria offer the opportunity to study the evolutionary processes of these $R$ genes among the closely related species.

Results: In this study, 325, 155, 190, 187, and 133 NBS-LRRs were discovered from F. x ananassa, F. iinumae, F. nipponica, F. nubicola, and F. orientalis, respectively. Together with the 144 NBS-LRR genes from F. vesca, a total of 1134 NBS-LRRs containing 866 multi-genes comprised 184 gene families across the six Fragaria genomes. Extremely short branch lengths and shallow nodes were widely present in the phylogenetic tree constructed with all of the NBS-LRR genes of the six strawberry species. The identities of the orthologous genes were highly significantly greater than those of the paralogous genes, while the Ks ratios of the former were very significantly lower than those of the latter in all of the NBS-LRR gene families. In addition, the Ks and Ka/Ks values of the TIR-NBS-LRR genes (TNLs) were significantly greater than those of the non-TIR-NBS-LRR genes (non-TNLs). Furthermore, the expression patterns of the NBS-LRR genes revealed that the same gene expressed differently under different genetic backgrounds in response to pathogens.

Conclusions: These results, combined with the shared hotspot regions of the duplicated NBS-LRRs on the chromosomes, indicated that the lineage-specific duplication of the NBS-LRR genes occurred before the divergence of the six Fragaria species. The $K s$ and $K a / K s$ ratios suggested that the TNLs are more rapidly evolving and driven by stronger diversifying selective pressures than the non-TNLS.
\end{abstract}

Keywords: NBS-LRR genes, Fragaria species, Disease resistance genes, Lineage-specific duplication, Duplication time

\section{Background}

Plant disease resistance genes ( $R$ genes), important components of the innate immune systems of plants, specify particular recognition events with pathogen avirulence (avr) genes, which confer resistance to the invasion of viral, bacterial, fungal, oomycete, nematode and insect pathogens [1,2]. Although the $R$ genes have such a broad spectrum of resistance, they only encode five types of proteins, in which NBS-LRR (nucleotide binding sitesleucine-rich repeat) genes are the largest class of plant $R$ genes [3]. The NBS-LRR genes contain an N-terminal

\footnotetext{
* Correspondence: yzhong@njau.edu.cn; zmc@njau.edu.cn

${ }^{1}$ College of Horticulture, Nanjing Agricultural University, Nanjing 210095, China

Full list of author information is available at the end of the article
}

domain, a conserved nucleotide-binding site (NBS) domain and a $\mathrm{C}$-terminal variable leucine-rich repeat (LRR) domain. The NBS domain functions as the sites of ATP and GTP binding and hydrolyzation, and the LRR domain is critical for protein-protein interactions and peptide-ligand binding [4]. The NBS-LRR proteins are found to be nuclear or nuclear and cytoplasmic, and specifically recognize pathogenic effectors and trigger down-stream signal transduction pathways, such as hypersensitive response (HR) and programmed cell death [5-7]. The NBS-LRR genes can be further divided according to their N-terminal domain features: TIRNBS-LRR genes have an N-terminal Toll/interleukin-1 receptor (TIR) domain and non-TIR-NBS-LRR genes contain a coiled-coil domain (CC), an RPW8/CC $C_{R}$ 
domain (RPW8, $\mathrm{CC}_{\mathrm{R}}$ domain resembles RPW8 domain) or some other domain (X) [8-12]. A genomewide investigation of the NBS-LRR genes has been conducted in Arabidopsis thaliana, Oryza sativa, Vitis vivifera, Castanea mollissima, Actinidia chinensis, Fragaria vesca, Malus domestica, Pyrus bretschneideri, Prunus persica, Prunus mume, and so on [13-18]. However, the NBS-LRR genes always vary in number among these plant genomes, because of the different scales of gene duplications in specific species to confront the rapidly changing pathogens in the environment $[19,20]$.

The genus Fragaria belongs to the family Rosaceae, has seven basic chromosomes $(x=7)$, and is considered to comprise one octoploid cultivated species $(F . x$ ananassa, $2 \mathrm{n}=8 \times=56)$ and 24 wild species, containing 13 diploids $(2 n=2 \times=14)$, five tetraploids $(2 n=4 \times=28)$, one hexaploid $(2 n=6 x=42)$, four octoploids $(2 n=8 \times$ $=56)$ and one decaploid $(2 \mathrm{n}=10 x=70)[21,22]$. The origin of $F . x$ ananassa is a natural hybridization in eighteenth century in Europe between two octoploids, the South American F. chiloensis and North American $F$. virginiana [23]. The cultivated $F . x$ ananassa is an economically-important crop species around the world, and suffers from a variety of diseases causing heavy financial losses, including powdery mildew, leather rot and anthracnose, which prompted increased focus on the $R$ genes and disease resistance breeding in strawberry crops. Wild species are widely known to be rich in broad disease resistance and have been successfully incorporated into cultivated crops through breeding and biotechnology [24]. Therefore, the recently released whole genome sequences of $F . x$ ananassa and four wild species, F.iinumae, F. nipponica, F. nubicola and F. orientalis, provide an opportunity to conduct the genome-wide identification of NBS-LRR genes and uncover the evolutionary processes of these $R$ genes among the Fragaria genomes [25] in relation to $F$. vesca, the reference strawberry species [14].

In this study, 1134 NBS-LRR genes and 184 gene families were identified in six Fragaria genomes, including 38 TNL gene families and 146 non-TNL gene families. In addition, our results suggested that the NBS-LRR genes duplicated before the divergence of the six species, according to the analysis of phylogenetic tree, synonymous substitutions and chromosome locations of the NBS-LRR genes among the six Fragaria genomes. Meanwhile, selective pressure and frequent sequence exchanges were also conducted, indicating the different evolutionary rates between TNL and non-TNL genes. Furthermore, the expression profiles of the NBS-LRR genes after pathogen infection showed that some $R$ genes are especially expressed under various genetic backgrounds.

\section{Methods}

\section{Identification of NBS-LRR genes}

The whole genome sequences and annotations of $F$. $\mathrm{x}$ ananassa, $F$. iinumae, $F$. nipponica, $F$. nubicola, and $F$. orientalis were downloaded from the FTP site of Strawberry GARDEN (ftp://ftp.kazusa.or.jp/pub/strawberry/) [25]. The NBS-LRR genes in F. vesca were previously identified in our study [14]. Both BLAST and Hidden Markov Model (HMM) searches were employed to identify NBS-LRR genes in the five Fragaria species. The standard NB-ARC domain (PF00931) from the Pfam website (http://pfam.xfam.org/) was used as query sequence to TBLASTN against the whole-genome nucleotide coding sequences (CDSs) in each Fragaria species with an E-value $\leq 10^{-4}$. In addition, the HMM profiles of the NB-ARC domain were also retrieved from Pfam and searched against the whole-genome protein sequences in each Fragaria species in hmmer 3.1 (http://hmmer.org) by using the default parameter settings. All of the hits obtained from BLAST and HMM searches were merged, and the redundancies were eliminated.

Pfam analysis was performed to verify the presence of NB-ARC domain and LRR motif in all non-redundant candidate hits, and SMART protein motif analysis (http://smart.embl-heidelberg.de/) was employed to improve the accuracy of LRR identification. Finally, the identified NBS-LRR genes were further examined whether they encoded TIR, RPW8 or CC domains by using Pfam and COILS (http://embnet.vital-it.ch/software/COILS_form.html).

\section{Multi-gene families of NBS-LRR genes and data analysis}

An all-versus-all BLASTN search was processed in all the TNL and non-TNL CDSs among the six Fragaria genomes with an E-value of 1 . Then, coverage of $>60 \%$ and identify between sequences of $>60 \%$ were used to divide the TNLs and the non-TNLs into multi-gene families, respectively.

The CDS alignment of each gene family was obtained based on aligning their protein sequences using Clustalw2.0 [26], which was used to calculate nonsynonymous substitutions $(K a)$, synonymous substitutions $(K s)$ and ratio of nonsynonymous to synonymous substitutions $(\mathrm{Ka} / \mathrm{Ks})$ using MEGA v6.06 [27], and investigate sequence exchange events through GENECONV 1.81 (https://www.math.wustl.edu/ sawyer/mbprogs/) with default option of 10,000 permutations $(P$-value $<0.05)$. For all gene families including three or more members, their CDS alignments were applied to detect positive selective pressure by using the following two models in the PAML4 package [28]: (1) the site model was set as model $=0$, models M7 (beta) and M8 (beta- $\omega$ ) (NS site $=78$ ), and the critical values of chi-square 
test $5.991(p<0.05, d f=2)$ and $9.210(p<0.01, d f=2)$ were also applied in the LR test between M7 and M8; (2) the parameters of branch model were model $=0$ and model 0 (NS site $=0$ ).

\section{Phylogenetic tree of NBS-LRR genes}

The nucleotide sequences of all NB-ARC domain regions were aligned with the MUSCLE program using the default settings through MEGA v6.06 [27]. Subsequently, a Maximum Likelihood (ML) phylogenetic tree was constructed using the Jukes-Cantor model of nucleotide evolution and 1000 replicates in FastTree v2.1.8 [29]. The same methods were also used to construct another two phylogenetic trees of the TNL and non-TNL gene families, respectively.

\section{Physical distributions of NBS-LRR genes on chromosomes}

Among the six species, the detailed genome annotation was only available for the genome of $F$. vesca. To acquire the position information of the NBS-LRR genes from the other five species, a BLAST analysis was performed by using the CDSs of NBS-LRRs in the five genomes against the genome sequences of $F$. vesca. Then, each chromosome was divided into different regions based on $1 \mathrm{Mb}$, and the gene numbers were counted in each region of the chromosomes. The hotspot regions of the NBS-LRR genes were further examined among the six species by using Duncan tests $(P<0.05)$ across each chromosome.

\section{Heatmap of NBS-LRR genes after pathogen infection}

The RNA-seq data of two F. vesca accessions, namely Hawaii $4(\mathrm{HW})$ and Yellow Wonder 5AF7 (YW), infected by powdery mildew (Podosphaera aphanis) were obtained from ENA (http://www.ebi.ac.uk/ena/data/ view/PRJEB4896) [30], including six samples, namely
HW 0 (control), HW 1dai (day after infection), HW 8dai, YW 0 (control), YW 1dai and YW 8dai. The differentially expressed genes (DEGs) in HW (0 vs. 1 dai, 0 vs. 8 dai and 1dai vs.8dai) and YW (0 vs. 1dai, 0 vs. 8 dai and 1dai vs.8dai) were analyzed using the edgeR package with $|\operatorname{logFC}| \geq 2$ and FDR $\leq 0.05$.

The expression quantities of the $F$. vesca genes in response to Phytophthora cactorum were downloaded, including HW 0 and HW 2 dai [31]. The differentially expressed NBS-LRR genes were further screened on the basis of above-mentioned standards.

The heatmaps were drawn according to the expression profiles of filtered differentially expressed NBS-LRRs by the $\mathrm{R}$ project.

\section{Results}

\section{Identification of NBS-LRR genes in six Fragaria species}

According to searches for NBS-LRRs by using BLAST and HMM methods, a total of 1134 NBS-LRR genes were detected from the six Fragaria genomes, and 325, 155, 190, 187, and 133 NBS-LRRs from $F . \mathrm{x}$ ananassa, $F$. iinumae, F. nipponica, F. nubicola, and F. orientalis, respectively (Table 1 ). As expected, the octaploid $F$. x ananassa had the largest gene number compared with its five wild species, but less than 4-fold numbers of the NBS-LRRs from the diploid genomes. The tetraploid species, $F$. orientalis, possessed the least NBS-LRR genes among the six Fragaria species, instead of the second largest number. These might be attributed to the fact that the genome sizes of $F$. $\mathrm{x}$ ananassa and $F$. orientalis were underestimated during the whole genome sequencing [25]. In the four diploid Fragaria species, the NBSLRR gene numbers normally ranged in a narrow scope, from 144 ( $F$. vesca) to 190 (F. nipponica), because their similar genome sizes were close to the true genome values $(\sim 200 \mathrm{Mb})[25]$.

Table 1 NBS-LRR genes in six Fragaria genomes

\begin{tabular}{|c|c|c|c|c|c|c|c|c|}
\hline $\begin{array}{l}\text { Predicted protein } \\
\text { domains }\end{array}$ & $\begin{array}{l}\text { Letter } \\
\text { code }\end{array}$ & $\begin{array}{l}\text { F. } x \text { ananassa } \\
\text { (octaploid) }\end{array}$ & $\begin{array}{l}\text { F. iinumae } \\
\text { (diploid) }\end{array}$ & $\begin{array}{l}\text { F. nipponica } \\
\text { (diploid) }\end{array}$ & $\begin{array}{l}\text { F. nubicola } \\
\text { (diploid) }\end{array}$ & $\begin{array}{l}\text { F. orientalis } \\
\text { (tetraploid) }\end{array}$ & $\begin{array}{l}\text { F. vesca } \\
\text { (diploid) }\end{array}$ & Total \\
\hline NBS-LRR & & 325 & 155 & 190 & 187 & 133 & 144 & 1134 \\
\hline TIR-NBS-LRR & TNL & 97 & 41 & 33 & 36 & 17 & 23 & 247 \\
\hline TIR-NBS-LRR & TNL' & 86 & 36 & 30 & 34 & 16 & 21 & 223 \\
\hline TIR-TIR-NBS-LRR & TTNL & 11 & 5 & 3 & 2 & 1 & 2 & 24 \\
\hline Non-TIR-NBS-LRR & Non-TNL & 228 & 114 & 157 & 151 & 116 & 121 & 887 \\
\hline CC-NBS-LRR & $\mathrm{CNL}$ & 73 & 40 & 43 & 55 & 21 & 60 & 292 \\
\hline CC-NBS-LRR & $C N L^{\prime}$ & 68 & 37 & 42 & 49 & 21 & 48 & 265 \\
\hline RPW8-CC-NBS-LRR & RPW $8-\mathrm{CNL}$ & 5 & 3 & 1 & 6 & 0 & 12 & 27 \\
\hline$X-N B S-L R R$ & $\mathrm{XNL}$ & 155 & 74 & 114 & 96 & 95 & 61 & 595 \\
\hline$X-N B S-L R R$ & $\mathrm{XNL^{ \prime }}$ & 149 & 69 & 114 & 95 & 95 & 50 & 572 \\
\hline RPW8-X-NBS-LRR & RPW8-XNL & 6 & 5 & 0 & 1 & 0 & 12 & 24 \\
\hline
\end{tabular}

Data from Zhong et al., [14] 
Among all the NBS-LRR genes in the six Fragaria genomes, there were more non-TNL genes (887) than TNLs (247), which were also detected in each Fragaria species, exhibiting significant difference between the $228,114,157,151,116$, and 121 non-TNL genes and the 97, 41, 33, 36, 17, and 23 TNL genes in $F . x$ ananassa, $F$. iinumae, $F$. nipponica, $F$. nubicola, $F$. orientalis and $F$. vesca ( $t$-test, $P<0.05)$. The nonTNLs contained $292 \mathrm{CNL}$ genes and $595 \mathrm{XNL}$ genes, including $265 \mathrm{CNL}, 27$ RPW8-CNLs, $572 \mathrm{XNL}$ and 24 RPW8-XNLs (Table 1). Interestingly, the RPW8$\mathrm{CNL}$ and RPW8-XNL, which had an N-terminal RPW8 domain (Pfam ID: PF05659) and could be named as RPW8-NBS-LRR (RNL), were also previously found in the non-TNL genes from Rosaceae plants, legume species, Chinese chestnut and grape genomes [14-16, 32].

\section{Multi-gene families of NBS-LRR genes in six Fragaria species}

All the NBS-LRR genes of the six Fragaria species were collected to detect the multi-gene families. In all, 184 gene families were found across the six Fragaria NBS-LRRs, containing 866 multi-genes, suggesting that $76.37 \%(866 / 1134)$ of all the NBS-LRR genes were included in the multi-gene families (Table 2). These gene families included 38 TNL gene families and 146 non-TNL gene families, with 185 TNL multigenes and 681 non-TNL multi-genes, respectively, but showing similar proportions of multi-gene between TNLs (74.90\%) and non-TNLs (76.78\%).
Although different numbers of multi-genes were identified in the six Fragaria genomes, there were four species with similar proportions of multi-genes around $75 \%$, including $75.38 \%$ in $F . x$ ananassa, $75.48 \%$ in $F$. iinumae, $75.79 \%$ in F. nipponica, and $79.86 \%$ in $F$. vesca, except the other two species, $F$. nubicola and $F$. orientalis, with the highest (83.96\%) and lowest (66.17\%) proportions, respectively. The similar ranges of large proportions were also detected in the TNL and non-TNL gene families of the six Fragaria species, ranging from $64.71 \%$ (F. orientalis) to $84.85 \%$ ( $F$. nipponica) and $66.38 \%$ ( $F$. orientalis) to 84.11\% (F. nubicola). However, there were copy number variations among the six Fragaria species in each gene family. In the TNL gene families, the gene numbers ranged from 0 to 5 in each species of each family, except that family0 had a wide range from 1 to 25. Similarly, in non-TNL gene families, the range of 0 to 5 could be found in each family, except family7, 22 and 24 with the ranges from 0 to 13 (Additional file 1 : Table S1).

The average identity in the NBS-LRR genes was $90.28 \%$ in TNL gene families and $90.89 \%$ in non-TNL gene families (Table 2). It was presented that the identity values of non-TNLs were significantly greater than those of TNLs (Additional file 2: Table S2, $t$-test, $P<0.05$ ). Moreover, the identity values between orthologs were very significantly greater than those between paralogs in both the TNL and non-TNL gene families ( $t$-test, $P<0.01$ ), indicating that orthologs have undergone less divergence events than paralogs in the six Fragaria NBS-LRR genes.

Table 2 Classification of NBS-LRR genes in six Fragaria species

\begin{tabular}{|c|c|c|c|c|c|c|c|}
\hline & F. $x$ ananassa & F. iinumae & F. nipponica & F. nubicola & F. orientalis & F. vesca & Total \\
\hline Number of single gene & 80 & 38 & 46 & 30 & 45 & 29 & 268 \\
\hline Number of TNL single gene & 26 & 14 & 5 & 6 & 6 & 5 & 62 \\
\hline Proportion of TNL single gene & $26.80 \%$ & $34.15 \%$ & $15.15 \%$ & $16.67 \%$ & $35.29 \%$ & $21.74 \%$ & $25.10 \%$ \\
\hline Number of non-TNL single gene & 54 & 24 & 41 & 24 & 39 & 24 & 206 \\
\hline Proportion of non-TNL single gene & $23.68 \%$ & $21.05 \%$ & $26.11 \%$ & $15.89 \%$ & $33.62 \%$ & $19.83 \%$ & $23.22 \%$ \\
\hline Number of multi-gene & 245 & 117 & 144 & 157 & 88 & 115 & 866 \\
\hline Proportion of multi-gene & $75.38 \%$ & $75.48 \%$ & $75.79 \%$ & $83.96 \%$ & $66.17 \%$ & $79.86 \%$ & $76.37 \%$ \\
\hline Number of gene family & & & 184 & & & & \\
\hline Number of TNL multi-gene & 71 & 27 & 28 & 30 & 11 & 18 & 185 \\
\hline Proportion of TNL multi-gene & $73.20 \%$ & $65.85 \%$ & $84.85 \%$ & $83.33 \%$ & $64.71 \%$ & $78.26 \%$ & $74.90 \%$ \\
\hline Number of TNL gene family & & & 38 & & & & \\
\hline Average identity of TNL gene family & & & $90.28 \%$ & & & & \\
\hline Number of non-TNL multi-gene & 174 & 90 & 116 & 127 & 77 & 97 & 681 \\
\hline Proportion of non-TNL multi-gene & $76.32 \%$ & $78.95 \%$ & $73.89 \%$ & $84.11 \%$ & $66.38 \%$ & $80.17 \%$ & $76.78 \%$ \\
\hline Number of non-TNL gene family & & & 146 & & & & \\
\hline Average identity of non-TNL gene family & & & $90.89 \%$ & & & & \\
\hline
\end{tabular}




\section{Phylogenetic tree of NBS-LRR genes among six Fragaria species}

To further detect the evolutionary pattern of the NBSLRR genes of the six Fragaria species, two unrooted phylogenetic trees of the NBS-region sequences were constructed by using FastTree software, including the TNL and non-TNL trees. For the phylogenetic tree of TNLs (Fig. 1a), it was clearly divided into two groups (group I and II) with average branch lengths 0.04 versus. 0.08 (default unit in MEGA 6), and showing highly significant difference between them $(t$-test, $P<0.01)$, which illustrated the evolutionary divergence between the two groups of Fragaria TNL genes. The non-TNL tree had

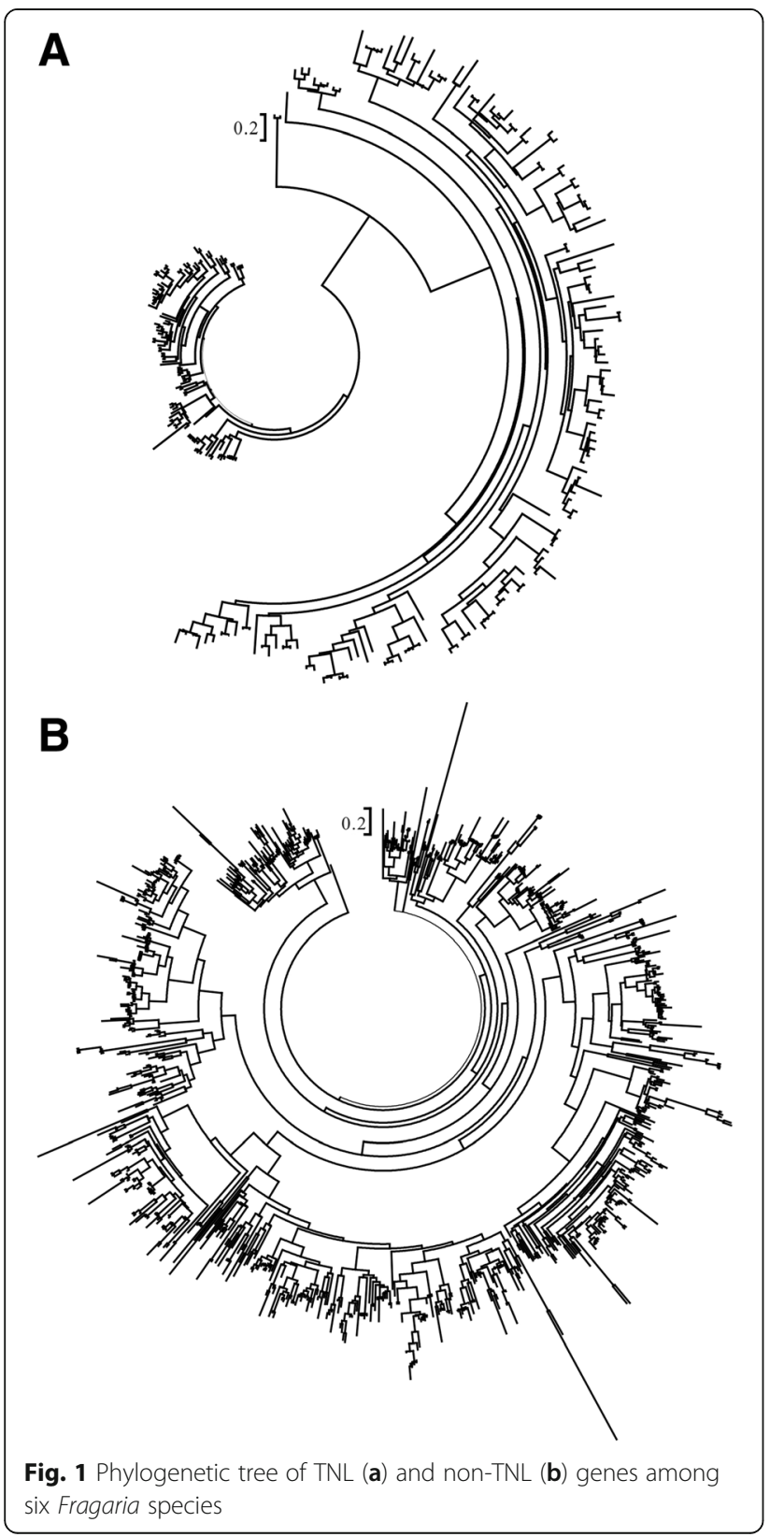

relatively more identical branch lengths and similar topologies compared with those in the TNL tree (Fig. 1). Although the average branch length of TNL genes (0.06) was just slightly greater than that of the non-TNL genes (0.059), both the TNL-group I and II had highly significantly different branch lengths from non-TNLs, respectively $(t$-test, $P<0.01)$.

In addition, a phylogenetic tree of all the NBS-LRR genes was constructed based on the same method (Additional file 3: Figure S1), including Fragaria lineage-specific duplicated clades consisting of orthologs from different Fragaria genomes, and speciesspecific duplicated clades composed by clustered paralogs. A majority of the NBS-LRRs were located in Fragaria lineage-specific duplicated clades rather than speciesspecific duplicated clades, and the topological structures of genes in lineage-specific duplicated clades were in accordance with the relationship of the six Fragaria species (Additional file 4: Figure S2). Both the Fragaria lineage-specific duplicated and the species-specific duplicated clades had genes with very short branch lengths and shallow nodes, indicating that there were and few divergence events between the Fragaria NBS-LRR genes with high identities.

Duplication time of NBS-LRR genes in six Fragaria species To detect the duplication time of the NBS-LRR genes among the six Fragaria species, Ks values of TNLs and non-TNLs were calculated in each gene family. Considering the saturation of nucleotide substitutions, only $K s$ values lower than 1 were retained for analysis.

On the whole, the TNL genes had greater median, mean and quartiles values than the non-TNL genes (Fig. 2a), and the Ks frequency of TNLs peaked at 0.3 to 0.9 greater than the peak range of 0 to 0.6 in non-TNLs (Additional file 5: Figure S3 C\&F). Moreover, the $K s$ values exhibited highly significant difference between the TNLs and non-TNLs $(t$-test, $P<0.01)$, which indicated that TNL genes had very significantly higher $K s$ than non-TNL genes. In addition, the $K s$ of paralogs were highly significantly greater than those of orthologs both in TNL and non-TNL gene families (Fig. 2b, $t$ test, $P<0.01)$. The lineage-specific duplications of NBS-LRR genes occurred before the species differentiation of the six Fragaria plants (Fig. 2).

\section{Nonsynonymous and synonymous substitution of NBS- LRR genes}

The ratio of nonsynonymous to synonymous nucleotide substitution $(K a / K s)$ is an important parameter indicating the strength of selective constraints. Positive selection is indicated by a $\mathrm{Ka} / \mathrm{Ks}$ ratio greater than 1 , and neutral selection is implied by a ratio equal to 1 , while purifying selection is indicated by a ratio less than 1 . To 

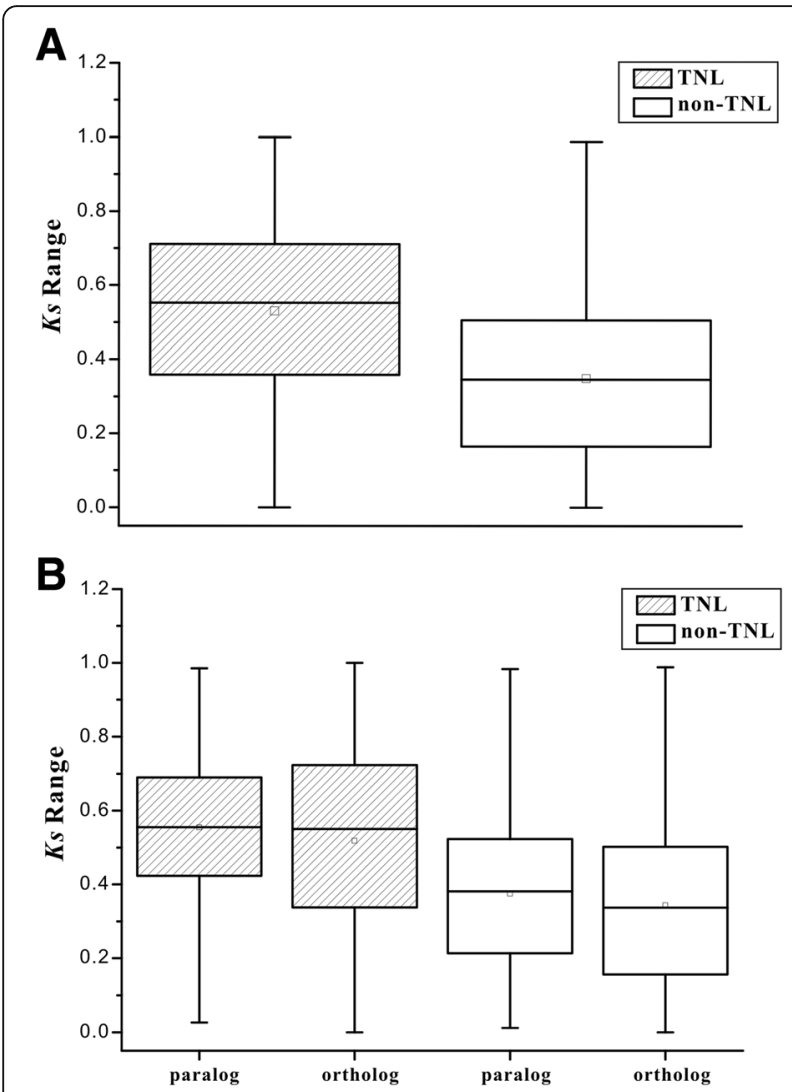

Fig. 2 The Ks ranges of NBS-LRR genes in six Fragaria species. a The Ks ranges of TNLS and non-TNLs in the six species. $\mathbf{b}$ The Ks ranges between paralogs and orthologs in TNLs and non-TNLs among the six species. The bars at the top and bottom of the whiskers mean maximum and minimum values; the top and bottom of the box represent third and first quartiles; the square and bar in the box mean average and median values

detect the direction and intensity of selection, we calculated the $\mathrm{Ka} / \mathrm{Ks}$ ratios in each of the TNL and non-TNL gene families among the six Fragaria genomes.

Most of the gene pairs (98\%), including TNLs and non-TNLs, had $\mathrm{Ka} / \mathrm{Ks}$ values less than 1 (Fig. 3), which indicated that most NBS-LRR genes were under purifying selection in the six Fragaria species. However, 12 and 79 gene pairs had $\mathrm{Ka} / \mathrm{Ks}$ ratios greater than 1 in the TNL and non-TNL gene families, respectively, illustrating that these NBS-LRR genes were driven by positive selection. In the case of the TNL gene families, a narrower distribution of the $\mathrm{Ka} / \mathrm{Ks}$ values was clearly exhibited than non-TNL gene families. Nevertheless, TNL genes had greater median and average values than those of non-TNLs, and the $K a / K s$ ratios showed highly significant difference between TNLs and non-TNLs $(t$-test, $P<0.01)$. It showed that TNL genes had significantly greater $\mathrm{Ka} / \mathrm{Ks}$ values than non-TNL genes, demonstrating that the TNLs are subject to stronger diversifying

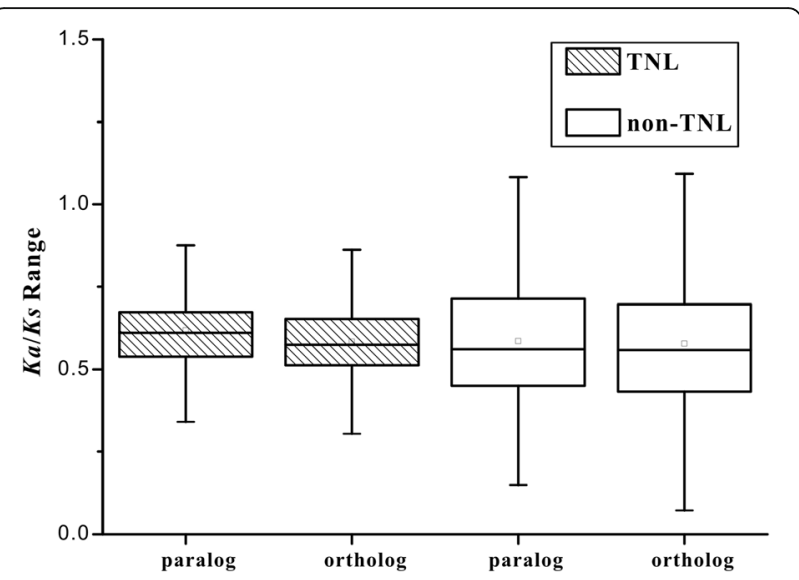

Fig. 3 The Ka/Ks ratios of NBS-LRR genes in genomes of six Fragaria species

selection and a faster evolutionary rate than the nonTNLs.

Furthermore, the paralogs had greater median, average and quartile values than the orthologs in TNLs and nonTNLs, respectively. Especially in TNL gene families, the $\mathrm{Ka} / \mathrm{Ks}$ ratios between paralogs and orthlogs displayed highly significant difference ( $t$-test, $P<0.01)$, showing that paralogs had significantly greater $K a / K s$ values than orthologs.

Selective forces on NBS-LRR genes in six Fragaria species To further confirm the evolutionary selective forces of NBS-LRR genes in the six Fragaria species, we also calculated the $\omega(d N / d S)$ and $2 \Delta \ln$ values by branch and site models of PAML4 in TNL and non-TNL gene families. In the two model tests, 105 gene families were estimated, containing $23 \mathrm{TNL}$ and 82 non-TNL gene families with three or more gene members (Tables 3 and $4)$. For the $\omega$ ratios, 99 gene families had average $\omega$ values less than 1 , indicating purifying selection was the main force acting on the 22 TNL and 77 non-TNL gene families. One TNL and two non-TNL gene families had average $\omega$ ratios approximately equal to 1 , suggesting that these gene families underwent neutral nonfunctionalization between duplicates. Moreover, three non-TNL gene families with $\omega$ ratios greater than 1 demonstrated that higher substitution rates were found in them caused by neofunctionalization [33]. In addition, LR tests were performed to detect the positive selection on amino acid sites represented by $2 \Delta \ln$ values. Among the $23 \mathrm{TNL}$ gene families, there were 15 families $(65.22 \%)$ had amino acid sites under significant $(2 \Delta \ln >5.991, P<0.05)$ or highly significant $(2 \Delta \ln >9.210, P<0.01)$ positive selection. However, $81.71 \%$ of the 82 non-TNL gene families had positively selected sites examined by significance $(2 \Delta \ln >5.991, P<0.05)$ or highly significance $(2 \Delta \ln >$ 9.210, $P<0.01)$ tests. It is worth mentioning that there 
Table 3 Positive selection and sequence exchange events of TNLs in six Fragaria species

\begin{tabular}{|c|c|c|c|c|c|}
\hline Family & $K a / K s^{a}$ & $\omega(d N / d S)^{b}$ & $2 \Delta \ln ^{c}$ & LR test ${ }^{c}$ & $\begin{array}{l}\text { Sequence exchange } \\
\text { events }{ }^{d}\end{array}$ \\
\hline family0 & 0.60 & 0.23 & 0.00 & & 0 \\
\hline family1 & 0.62 & 0.67 & 45.74 & $* *$ & 18 \\
\hline family2 & 0.77 & - & & & 0 \\
\hline family3 & 0.65 & 0.73 & 40.23 & $* *$ & 15 \\
\hline family4 & 0.37 & 0.38 & 0.54 & & 1 \\
\hline family5 & 0.73 & 1.01 & 110.93 & $* *$ & 14 \\
\hline family6 & 0.41 & 0.35 & 1.38 & & 0 \\
\hline family7 & 0.54 & 0.54 & 44.13 & $* *$ & 9 \\
\hline family8 & 0.96 & - & & & 0 \\
\hline family9 & 0.62 & 0.49 & 47.84 & $* *$ & 29 \\
\hline family 10 & 0.75 & - & & & 0 \\
\hline family11 & 0.57 & 0.58 & 14.81 & $* *$ & 5 \\
\hline family 12 & 0.89 & - & & & 0 \\
\hline family13 & 0.77 & 0.77 & 299.48 & $* *$ & 2 \\
\hline family14 & 0.51 & 0.49 & 101.49 & $* *$ & 5 \\
\hline family 15 & 0.59 & 0.61 & 25.08 & $* *$ & 2 \\
\hline family 16 & 0.22 & - & & & 0 \\
\hline family 17 & 0.85 & 0.85 & 9.70 & $* *$ & 4 \\
\hline family 18 & 0.79 & - & & & 0 \\
\hline family 19 & 0.35 & 0.33 & 3.78 & & 8 \\
\hline family 20 & 0.47 & 0.42 & 8.82 & * & 7 \\
\hline family21 & 0.78 & - & & & 0 \\
\hline family22 & 0.28 & 0.30 & 0.00 & & 1 \\
\hline family23 & 0.56 & 0.54 & 27.06 & $* *$ & 6 \\
\hline family24 & 0.51 & 0.45 & 4.64 & & 3 \\
\hline family 25 & 0.59 & 0.63 & 81.98 & $* *$ & 4 \\
\hline family 26 & 0.55 & - & & & 0 \\
\hline family27 & 0.67 & 0.61 & 28.33 & $* *$ & 4 \\
\hline family28 & 0.58 & - & & & 0 \\
\hline family29 & 0.63 & - & & & 0 \\
\hline family30 & 0.71 & - & & & 0 \\
\hline family31 & 0.54 & - & & & 0 \\
\hline family32 & 0.71 & 0.62 & 80.84 & $* *$ & 3 \\
\hline family33 & 0.41 & - & & & 0 \\
\hline family34 & 0.41 & 0.43 & 2.73 & & 0 \\
\hline family35 & 0.88 & - & & & 0 \\
\hline family36 & 0.26 & 0.15 & 0.00 & & 0 \\
\hline family37 & 0.60 & - & & & 0 \\
\hline
\end{tabular}

${ }^{a}$ Average $K a / K s$ ratio of each gene family by using MEGA6; ${ }^{\mathrm{b}} \omega(d N / d S)$ value of each gene family was calculated by using branch model in PAML software; ${ }^{c}$ $2 \Delta \mathrm{In}$ means the LR-test result using site model in PAML software; ${ }^{*}$ and ${ }^{* *}$ represent significant $(2 \Delta \ln >5.991, P<0.05)$ and highly significant $(2 \Delta \ln >$ $9.210, P<0.01$ ) tests for positive selection between model M7 and M8; ${ }^{d}$ Sequence exchange event shows the statistically significant sequence exchange events $(P<0.05)$ were 24,45 and 92 positively selected sites distributed in TIR domains, NB-ARC domains and LRR motifs in TNLs and 26, 285 and 465 positively selected sites in CC regions, NB-ARC domains and LRR motifs in nonTNLs. It was showed that in LRR motifs had more positively selected sites than NB-ARC and other domains in these NBS-LRR genes.

The sequence exchange events include gene conversion, recombination, and unequal crossing-over. In totally, 944 sequence exchange events occurred in the NBS-LRR gene families, including 140 in TNLs and 804 in non-TNLs, and $20.00 \%$ and $17.04 \%$ of sequence exchange events occurred between paralogs in TNL and non-TNL gene families, respectively. The sequence exchange events among paralogs ( 28 in TNLs and 137 in non-TNLs) could raise the sequence homogeneity within a species and the sequence divergence between species [34].

\section{Chromosomal distribution of NBS-LRR genes among the six Fragaria species}

To explore the chromosomal distribution of NBS-LRR genes, we calculated the gene numbers in each region of the chromosomes. In totally, the two largest gene numbers were found in chromosome 3 (254) and chromosome 6 (235), followed by in chromosome 5 (168) and the chromosome 7 (158), and then in chromosome 2 (79), chromosome 4 (70), and chromosome 1 (65). Although the gene number of NBS-LRRs was partly linked with chromosome lengths, the uneven distribution and the locational preference of Fragaria NBS-LRR genes were also found within the same chromosome or between the different chromosomes. For example, chromosome 3 has a crest region containing 19 genes, but it still has none gene in several regions; chromosome 6 displays a peak with 16 genes, while the peak of chromosome 1 is only five (Fig. 4).

Based on the locational preference of NBS-LRR genes, similar distributions were found on the same chromosomes among the different Fragaria species, demonstrating that the different species shared most of the highs and lows of gene numbers on each chromosome. The Duncan's test also detected the hotspot regions shared by different species on each chromosome, which are regions with significantly higher gene numbers than other regions within the same chromosomes $(P<0.05)$. As shown in Fig. 4, except chromosome 7, the other six chromosomes have one to three shared hotspot regions of NBS-LRR genes. Interestingly, there are two, two and one shared hotspot regions of NBS-LRR genes on the ends of chromosome 3, 6 and 2, respectively, which illustrated that $39 \%, 26 \%$ and $30 \%$ of the NBS-LRR genes experienced gene duplication events on telomeric areas or near telomeres. 
Table 4 Positive selection and sequence exchange events of non-TNLs in six Fragaria species

\begin{tabular}{|c|c|c|c|c|c|}
\hline Family & $\mathrm{Ka}_{\mathrm{a}} \mathrm{K} / \mathrm{Ks}$ & $\underset{b}{\omega}(d N / d S)$ & $2 \Delta \ln { }^{c}$ & $\underset{c}{\mathrm{LR} \text { test }}$ & $\begin{array}{l}\text { Sequence exchange } \\
\text { events }{ }^{d}\end{array}$ \\
\hline family0 & 0.45 & 0.42 & 35.48 & $* *$ & 11 \\
\hline family1 & 0.78 & 0.83 & 59.37 & $* *$ & 28 \\
\hline family2 & 0.59 & 0.59 & 75.22 & $* *$ & 39 \\
\hline family3 & 1.46 & 0.99 & 43.01 & $* *$ & 0 \\
\hline family4 & 0.64 & 0.72 & 4.67 & & 10 \\
\hline family5 & 0.93 & - & & & 0 \\
\hline family6 & 0.83 & 0.93 & 72.76 & $* *$ & 11 \\
\hline family7 & 0.58 & 0.68 & 73.55 & $* *$ & 10 \\
\hline family8 & 0.69 & 0.49 & 27.03 & $* *$ & 63 \\
\hline family9 & 0.63 & 0.54 & 15.19 & $* *$ & 5 \\
\hline family10 & 0.60 & 0.36 & 10.98 & $* *$ & 12 \\
\hline family11 & 0.91 & 0.97 & 62.72 & $* *$ & 5 \\
\hline family 12 & 0.67 & - & & & 0 \\
\hline family13 & 0.82 & 0.87 & 146.39 & $* *$ & 77 \\
\hline family14 & 1.14 & - & & & 0 \\
\hline family15 & 0.42 & 0.40 & 0.19 & & 4 \\
\hline family16 & 0.41 & - & & & 0 \\
\hline family17 & - & - & & & 0 \\
\hline family18 & 0.51 & 0.43 & 0.00 & & 0 \\
\hline family19 & 0.65 & 0.65 & 37.48 & $* *$ & 3 \\
\hline family20 & 0.79 & 0.93 & 129.67 & $* *$ & 5 \\
\hline family21 & 0.74 & 0.92 & 10.52 & $* *$ & 4 \\
\hline family22 & 0.68 & 0.58 & 25.75 & $* *$ & 119 \\
\hline family23 & 0.64 & 0.58 & 47.88 & $* *$ & 2 \\
\hline family24 & 0.45 & 0.50 & 23.82 & $* *$ & 4 \\
\hline family25 & 0.58 & 0.54 & 111.42 & $* *$ & 8 \\
\hline family26 & 0.57 & 0.59 & 74.25 & $* *$ & 18 \\
\hline family27 & 1.00 & 1.09 & 116.83 & $* *$ & 26 \\
\hline family28 & 0.72 & 0.62 & 18.65 & $* *$ & 0 \\
\hline family29 & 0.92 & - & & & 0 \\
\hline family30 & 0.94 & - & & & 0 \\
\hline family31 & 0.73 & - & & & 0 \\
\hline family32 & 0.96 & 0.87 & 47.42 & $* *$ & 16 \\
\hline family33 & 1.06 & 0.95 & 98.69 & $* *$ & 8 \\
\hline family34 & 0.71 & 0.44 & 1.14 & & 1 \\
\hline family35 & 0.62 & - & & & 0 \\
\hline family36 & 0.93 & - & & & 0 \\
\hline family37 & 0.65 & - & & & 0 \\
\hline family38 & 0.54 & 0.50 & 0.00 & & 1 \\
\hline family39 & 0.50 & 0.55 & 26.57 & $* *$ & 4 \\
\hline family40 & 0.78 & 0.77 & 6.29 & * & 0 \\
\hline family41 & 0.60 & - & & & 0 \\
\hline family42 & 0.66 & 0.65 & 179.47 & $* *$ & 36 \\
\hline
\end{tabular}

Table 4 Positive selection and sequence exchange events of non-TNLs in six Fragaria species (Continued)

\begin{tabular}{|c|c|c|c|c|c|}
\hline Family & ${ }_{\mathrm{a}}^{\mathrm{Ka} / \mathrm{Ks}}$ & $\underset{\mathrm{b}}{\omega}(d N / d S)$ & $2 \Delta \ln { }^{c}$ & $\underset{c}{\operatorname{LR} \text { test }}$ & $\begin{array}{l}\text { Sequence exchange } \\
\text { events } d\end{array}$ \\
\hline family43 & 0.42 & 0.52 & 13.77 & $* *$ & 0 \\
\hline family44 & 0.60 & - & & & 0 \\
\hline family45 & 0.95 & - & & & 0 \\
\hline family46 & 0.67 & 0.68 & 58.45 & $* *$ & 21 \\
\hline family47 & 0.31 & 0.34 & 160.78 & $* *$ & 5 \\
\hline family48 & 0.51 & - & & & 0 \\
\hline family49 & 0.27 & - & & & 0 \\
\hline family50 & 0.71 & 0.88 & 188.51 & ** & 6 \\
\hline family51 & 0.47 & 0.44 & 69.96 & $* *$ & 15 \\
\hline family52 & 0.81 & - & & & 0 \\
\hline family53 & 0.54 & - & & & 0 \\
\hline family54 & 0.65 & 0.58 & 34.41 & $* *$ & 23 \\
\hline family55 & 1.70 & 2.23 & 113.38 & $* *$ & 1 \\
\hline family56 & 0.66 & 0.49 & 10.66 & $* *$ & 10 \\
\hline family57 & 0.51 & 0.32 & 0.00 & & 2 \\
\hline family58 & 0.55 & 0.42 & 15.31 & $* *$ & 1 \\
\hline family59 & 0.25 & 0.34 & 18.49 & $* *$ & 1 \\
\hline family60 & - & - & & & 0 \\
\hline family61 & 0.84 & - & & & 0 \\
\hline family62 & 0.67 & - & & & 0 \\
\hline family63 & 0.17 & - & & & 0 \\
\hline family64 & 0.71 & 0.73 & 159.69 & $* *$ & 16 \\
\hline family65 & 0.45 & 0.50 & 8.95 & * & 25 \\
\hline family66 & 0.92 & 0.88 & 36.06 & $* *$ & 0 \\
\hline family67 & 0.44 & 0.15 & 0.00 & & 0 \\
\hline family68 & 0.82 & - & & & 0 \\
\hline family69 & 0.55 & 0.32 & 8.34 & * & 1 \\
\hline family70 & 1.16 & 0.47 & 57.04 & $* *$ & 2 \\
\hline family71 & 0.70 & - & & & 0 \\
\hline family72 & 0.93 & 1.16 & 7.52 & * & 0 \\
\hline family73 & 0.99 & - & & & 0 \\
\hline family74 & 0.57 & 0.57 & 62.86 & $* *$ & 4 \\
\hline family75 & 0.63 & 0.80 & 4.68 & & 0 \\
\hline family76 & 0.58 & 0.57 & 9.64 & $* *$ & 6 \\
\hline family77 & 0.59 & 0.66 & 21.23 & $* *$ & 0 \\
\hline family78 & 0.62 & - & & & 0 \\
\hline family79 & 0.57 & 0.55 & 80.40 & $* *$ & 11 \\
\hline family80 & 0.67 & 0.67 & 297.98 & $* *$ & 7 \\
\hline family81 & 0.55 & 0.63 & 15.57 & $* *$ & 0 \\
\hline family82 & 2.48 & - & & & 0 \\
\hline family83 & 0.87 & - & & & 0 \\
\hline family84 & 1.25 & - & & & 0 \\
\hline family85 & 0.70 & 0.78 & 48.80 & $* *$ & 23 \\
\hline
\end{tabular}


Table 4 Positive selection and sequence exchange events of non-TNLs in six Fragaria species (Continued)

\begin{tabular}{|c|c|c|c|c|c|}
\hline Family & $\mathrm{Ka}_{\mathrm{a}} \mathrm{Ks}$ & $\underset{b}{\omega}(d N / d S)$ & $2 \Delta \ln { }^{c}$ & $\underset{c}{\operatorname{LR} \text { test }}$ & $\begin{array}{l}\text { Sequence exchange } \\
\text { events }{ }^{d}\end{array}$ \\
\hline family86 & 1.21 & 1.29 & 91.70 & $* *$ & 0 \\
\hline family87 & 0.99 & 0.91 & 397.48 & $* *$ & 6 \\
\hline family 88 & 0.89 & 1.09 & 27.11 & $* *$ & 3 \\
\hline family89 & 0.36 & 0.43 & 0.69 & & 0 \\
\hline family 90 & 0.33 & - & & & 0 \\
\hline family91 & 0.36 & 0.36 & 7.96 & * & 0 \\
\hline family92 & 0.31 & 0.32 & 0.75 & & 1 \\
\hline family93 & 0.42 & - & & & 0 \\
\hline family94 & 0.71 & - & & & 0 \\
\hline family95 & 0.72 & - & & & 0 \\
\hline family96 & 0.60 & - & & & 0 \\
\hline family97 & 0.87 & 0.89 & 54.59 & $* *$ & 3 \\
\hline family98 & 0.41 & 0.36 & 56.24 & $* *$ & 0 \\
\hline family99 & 0.58 & 0.54 & 3.18 & & 0 \\
\hline family100 & 0.25 & 0.22 & 1.64 & & 21 \\
\hline family101 & 0.56 & 0.61 & 9.90 & $* *$ & 15 \\
\hline family 102 & 0.90 & - & & & 0 \\
\hline family103 & 0.77 & - & & & 0 \\
\hline family104 & 0.61 & 0.68 & 61.66 & $* *$ & 6 \\
\hline family105 & 0.60 & 0.53 & 20.30 & $* *$ & 0 \\
\hline family106 & 0.26 & - & & & 0 \\
\hline family107 & 0.70 & 0.68 & 22.56 & $* *$ & 18 \\
\hline family108 & 0.49 & - & & & 0 \\
\hline family109 & 0.29 & 0.32 & 0.00 & & 0 \\
\hline family110 & 0.45 & - & & & 0 \\
\hline family111 & 0.60 & 0.45 & 14.82 & $* *$ & 1 \\
\hline family112 & 0.40 & 0.44 & 0.00 & & 0 \\
\hline family113 & 0.55 & 0.76 & 12.69 & $* *$ & 0 \\
\hline family114 & 0.76 & - & & & 0 \\
\hline family115 & 0.37 & - & & & 0 \\
\hline family116 & 0.76 & 0.80 & 102.63 & $* *$ & 7 \\
\hline family117 & 0.69 & 0.47 & 9.51 & $* *$ & 2 \\
\hline family118 & 0.68 & 0.60 & 46.89 & $* *$ & 3 \\
\hline family119 & - & - & & & 0 \\
\hline family120 & 0.42 & - & & & 0 \\
\hline family 121 & 0.24 & - & & & 0 \\
\hline family 122 & 0.20 & 0.26 & 0.41 & & 0 \\
\hline family 123 & 0.50 & - & & & 0 \\
\hline family124 & 1.62 & 0.77 & 72.18 & $* *$ & 1 \\
\hline family 125 & 0.73 & 0.84 & 9.74 & $* *$ & 1 \\
\hline family 126 & 0.62 & - & & & 0 \\
\hline family 127 & 0.34 & - & & & 0 \\
\hline family 128 & 0.53 & 0.51 & 22.29 & $* *$ & 6 \\
\hline
\end{tabular}

Table 4 Positive selection and sequence exchange events of non-TNLs in six Fragaria species (Continued)

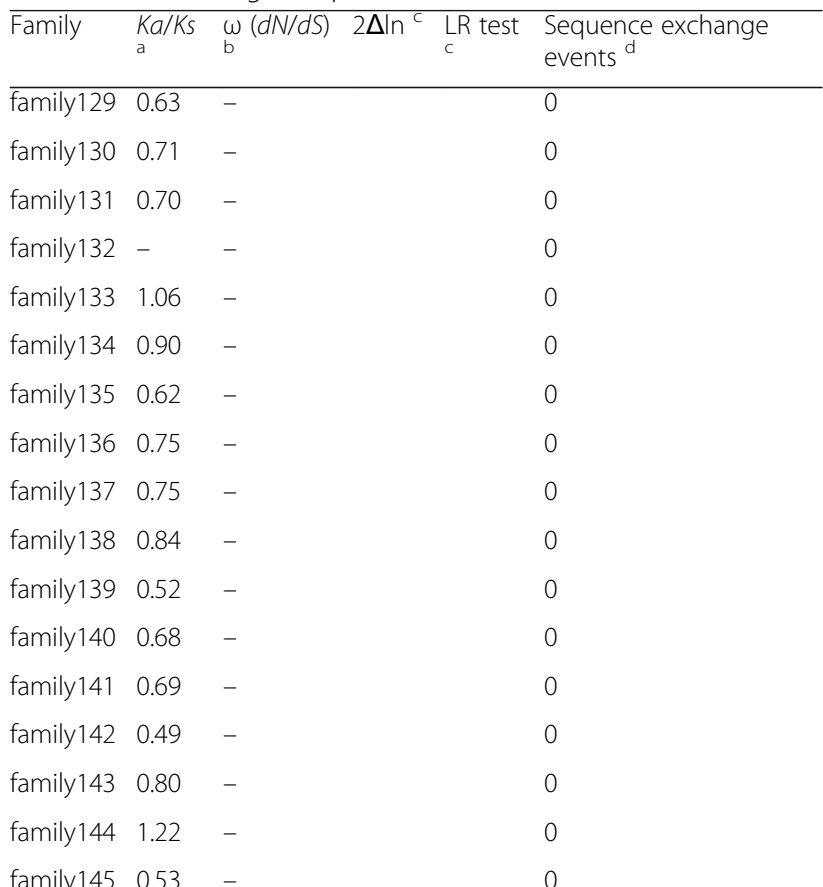

A Average $K a / K s$ ratio of each gene family by using MEGA6; ${ }^{\circ} \omega(d N / d S)$ value of each gene family was calculated by using branch model in PAML software; ${ }^{c}$ $2 \Delta \mathrm{In}$ means the LR-test result using site model in PAML software; * and ** represent significant $(2 \Delta \ln >5.991, P<0.05)$ and highly significant $(2 \Delta \mathrm{ln}>$ $9.210, P<0.01)$ tests for positive selection between model M7 and M8; ${ }^{d}$ Sequence exchange event shows the statistically significant sequence exchange events $(P<0.05)$

\section{Expression profiles of differentially expressed NBS-LRR genes after infection of powdery mildew}

Among all 144 NBS-LRR genes of $F$. vesca, we screened 25 NBS-LRR genes exhibiting differentially expression based on the RNA-seq data from two $F$. vesca accessions, Hawaii $4(\mathrm{HW})$ and Yellow Wonder 5AF7 (YW), after infection with powdery mildew [30]. Although different NBS-LRR genes showed different expression levels in the two accessions, the same genes displayed similar expression pattern between the two accessions (Fig. 5). For example, gene24119 showed continuous upregulation in both $\mathrm{HW}$ and YW; gene00463 manifested sustainable down-regulation; and gene12206 exhibited slight down-regulation first and then, obvious upregulation during the infection processes in the two accessions. However, in general, the same genes had higher expression levels in HW than those in YW, such as, the expression levels of gene15578 in HW 8dai vs. YW 8dai.

Twenty-two NBS-LRR genes were up-regulated and only three of them were down-regulated genes, which indicated these NBS-LRR genes might participate in the response to infection of $P$. aphanis. Among the 22 upregulated NBS-LRR genes, 14 of them exhibited increased expression levels both in HW and YW, and 

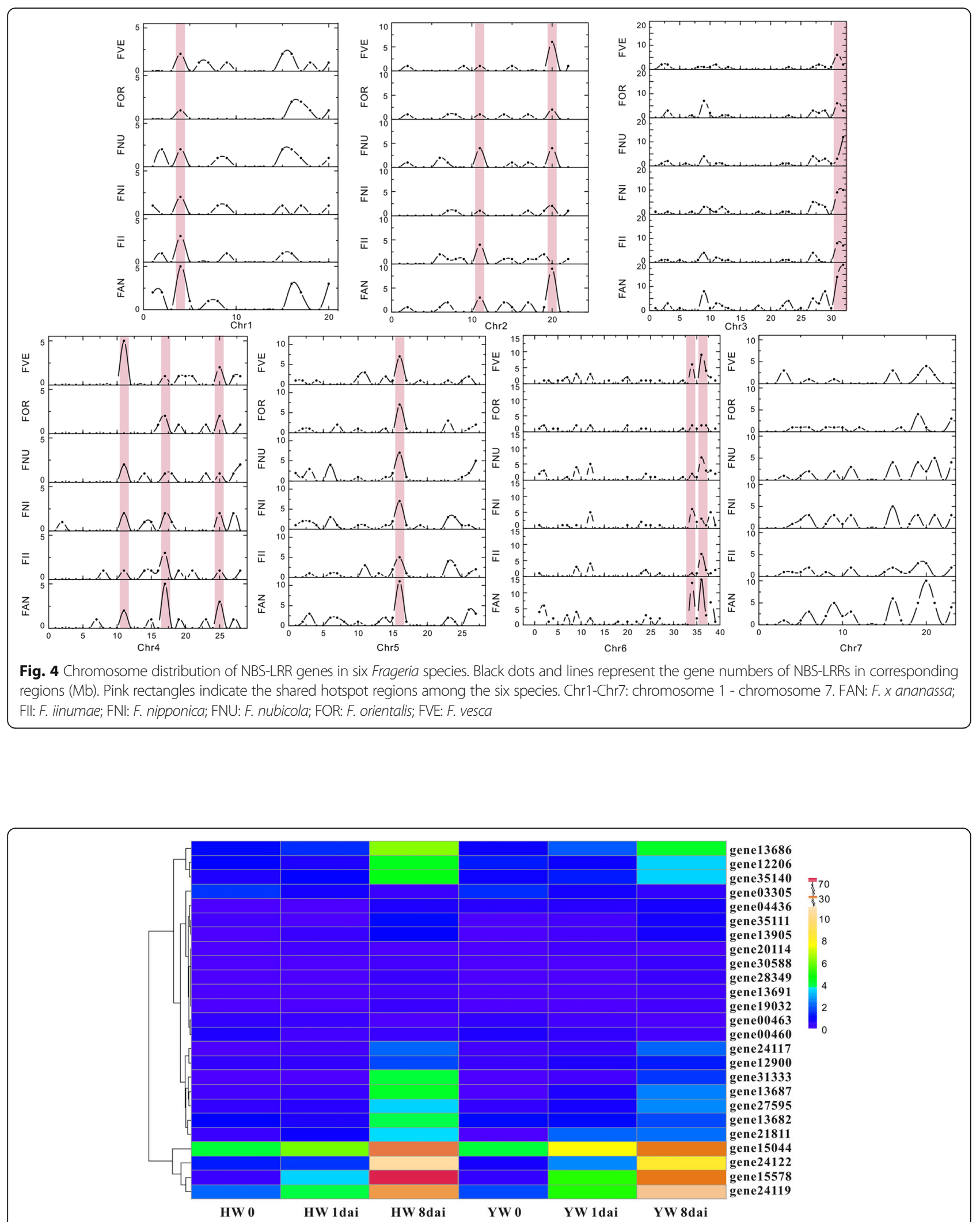

Fig. 5 Heatmap of differentially expressed NBS-LRR genes in two F. vesca accessions (Hawaii 4 and Yellow Wonder 5AF7) after infection with powdery mildew. HW: Hawaii 4; YW: Yellow Wonder 5AF7; HW 0 \& YW 0 mean control groups; "dai" represents day after infection. The scale bar means expression levels, represented by Fragments per Kilobase of transcript per Million mapped fragments (FPKM) value 
eight genes up-regulated only in HW. Interestingly, four up-regulated genes both in HW and YW includes gene15044, gene24122, gene15578, and gene24119 (Fig. 5), exhibiting prominent up-regulated expression levels compared with other genes. The three genes (gene15044, gene24122, and gene24119) with a certain amount of expression levels in controls (HW 0 and YW 0 ), and then showed steadily up-regulation to high expression levels. In contrast, gene15578 had very low expression in control groups, but very high expression in HW 8dai and YW 8dai, and its expression quantity in HW 8dai was the highest one among all the NBS-LRR genes from the two accessions.

\section{Expression profiles of differentially expressed NBS-LRR genes after infection with $P$. cactorum}

According to the transcriptome data of F. vesca Hawaii 4 infected with $P$. cactorum [31], 12 NBS-LRR genes were considered as DEGs, including five up-regulated genes and seven down-regulated genes (Fig. 6). Among the 12 genes, most of them had already exhibited different levels of expression in control group (HW 0), and then showed various expression levels in HW 2dai. For example, the up-regulated gene15578 and gene13684 had baseline expression levels in HW 0 and then showed the two highest expression levels in HW 2dai compared with other genes; and in down-regulated genes, gene04301 had the highest expression level in HW 0, then it decreased to a relative low expression level in HW 2dai. Interestingly, three of the five up-regulated genes also displayed differentially up-regulated expression after infection with powdery mildew (Figs. 5 and 6).

\section{Discussion}

\section{Lineage-specific duplication driven expansion of NBS-} LRRs before divergence of six Fragaria species

Plant NBS-LRR genes are numerous owing to a large amount of gene duplications in various genomes [15-17, 35]. Lineage-specific duplications play an important role in amplification and divergence of NBS-LRR genes in the Fabaceae, Solanaceae and Asteraceae [3, 36, 37], which were also detected in the NBS-LRR genes of the six Fragaria genomes, resulting in an increase of a gene family co-occurring in two or more close relatives from the common ancestor. This phenomenon was evidenced by in the phylogenetic tree that demonstrate that most of the NBS-LRR genes duplicated in the common ancestor genome of the six species, and then retained along with a small number of species-specific duplications after the speciation of the six species, because the young genus Fragaria originated from 1.0-4.1 MYA and the very close relationship between Fragaria species [38]. However, species-specific duplication principally contributed to NBS-LRR gene expansion in five Rosaceae species [14]. This difference is attributed to the relatively longer genetic distance between strawberry ( $F$. vesca) and the four Rosaceae species (apple, pear, peach and mei), but the six Fragaria species are close relatives with very recent origin dates [38]. Therefore, the NBS-LRR genes are largely attributed to the lineage-specific duplication events in denomination of six closely related Fragaria species.

Moreover, most of the peak and valley values of NBSLRR gene numbers were similar on the same chromosomes between the different species (Fig. 4), especially the shared hotspot regions of NBS-LRR genes. The

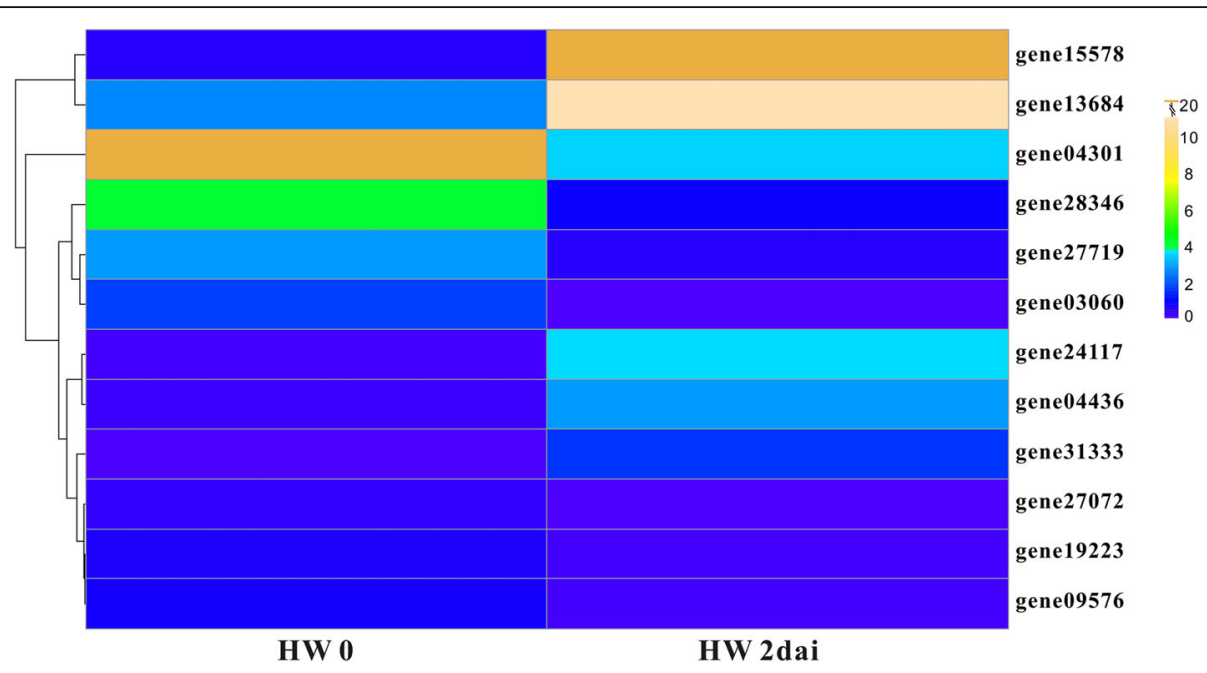

Fig. 6 Heatmap of differentially expressed NBS-LRR genes in F. vesca Hawaii 4 after infection with Phytophthora cactorum. HW: Hawaii 4; HW 0 means control group; "dai" represents day after infection. The scale bar means expression levels, represented by Fragments per Kilobase of transcript per Million mapped fragments (FPKM) value 
results further support the fact that these genes underwent lineage-specific duplications in the common ancestor of the six Fragaria plants. Although introgression occurred between the Fragaria genomes, the high levels of conserved colinearity and macrosynteny between diploid and octoploid strawberries retained the hotspot NBS-LRR genes in the corresponding regions during the polyploidization from diploid to octoploid Fragaria [39].

In addition, the very high average identities were detected in TNL gene families and non-TNL gene families in all six Fragaria genomes, further illustrating that the close genetic relationships between the six species leading to the relative less divergence events between Fragaria NBS-LRR genes after gene duplications. The very significantly higher identities between orthologs than those between paralogs in both TNLs and nonTNLs $(t$-test, $P<0.01)$ suggest that more orthologs preferred to locate in NBS-LRR multi-gene families than paralogs. Furthermore, the $K s$ value between paralogs or orthologs, which is the molecular clock of duplication time of genes in one species, or the divergence time of different species, respectively [40], revealed that the paralogous genes had highly significantly greater $K s$ and $\mathrm{Ka} / \mathrm{Ks}$ values than those of orthologous genes in NBSLRRs $(P<0.01)$, manifesting that paralogs evolved faster than orthologs, and the NBS-LRR genes are under faster evolutionary processes intra-species instead of interspecies among the six Fragaria genomes. Thus, most of the duplication events of Fragaria NBS-LRRs were lineage-specific duplications which occurred before the divergence of the six Fragaria species.

\section{Distinct evolutionary histories between TNL and non-TNL gene families}

Plant NBS-LRR genes are believed to share a common ancestor with ancient origination, which could be classified into two major types, TNLs and nonTNLs, according to the presence of the TIR, CC or X in the N-terminal domains [41].

The TNL and non-TNL genes located separately in phylogenetic tree constructed by the NBS domains in the Fragaria genomes (Additional file 3: Figure S1), legume family and other plants [3, 14, 32, 42]. In addition, TNL and non-TNL genes differ in terms of the topologies of phylogenetic analysis, especially the distinct branch lengths between the two type genes. Previous studies have revealed that the branch lengths between TNL genes were significantly longer than those between non-TNLs in A. thaliana and A. lyrata [19]. Here, branches were slightly longer in TNLs than those in non-TNLs, indicating that TNL genes might evolve faster than non-TNLs on the whole. More complex phenomena were uncovered that the phylogenetic tree of TNL genes had two distinct groups (group I and II). The branch lengths of non-TNLs were significantly longer than those in TNL group I and significantly shorter than TNL group II $(P<0.01)$, which manifested the different evolutionary patterns between the TNL and non-TNL genes.

The duplication of NBS-LRR genes in the six Fragaria genomes also provided opportunities to detect the evolutionary rates between TNL and non-TNL genes. The diversity and $K s$ values of TNL duplicates were significantly higher than those of non-TNLs $(P<0.01)$, consistent with the previous studies in Arabidopsis, soybean, and apple genomes [14, 19, 43], which might suggest that there are different evolutionary pattern between the TNLs and non-TNLs.

Our results demonstrated that TNL genes were under stronger selective pressures compared with non-TNLs, which were also reported in Arabidopsis relatives, five Rosaceae plants and soybean genomes [14, 19, 43]. However, the opposite results were found that $\mathrm{Ka} / \mathrm{Ks}$ ratios were lower in TNLs than in non-TNL genes from poplar, etc. $[16,37]$. The contrary phenomena on evolution of TNLs and non-TNLs might be due to different plants growing in diverse environments along with different life cycles and developmental conditions [14]. Therefore, TNLs and non-TNLs may have diverse evolutionary patterns to adapt to their corresponding pathogens in specific environments.

\section{$R$ genes differentially respond to pathogens with different genetic backgrounds}

Presentations of different responses to the same pathogens were commonly found in genetically heterogeneous accessions or varieties in strawberries [44-46]. For $P$. aphanis fungus infecting two $F$. vesca accessions, the white mycelia appear earlier and faster on the leaf of susceptible accession YW compared with the lesssusceptible HW, and more up-regulated and downregulated genes in HW than YW [30]. Therefore, although similar expression profiles of the NBS-LRR genes between the two F. vesca ecotypes (HW and YW), the less-susceptible HW exhibited higher expression levels and more pathogen-involved NBS-LRR genes than the susceptible YW (Fig. 5). The results indicated that the responses of $R$ genes were stronger in lesssusceptible accession than the susceptible one, which were consistent with previous studies on expression profiles of NBS-LRRs after infection with strawberry pathogens. Responses to Colletotrichum infection, for example, the FvNBSs manifested ecotype-specific responses between the moderately resistant ectype YW and the susceptible ecotype HLJ [44]; the response of genes was quicker and/or stronger in the moderate resistance cultivar 'Andana' than in the susceptible cultivar Camarosa [45]. The transcriptional responses of 
NBS-LRR genes showed more sensitive and fast-growing expression levels in less-susceptible cultivar 'Sweet Charlie' compared with those in susceptible 'Jiuxiang' [47]. For strawberry infection with $P$. cactorum, the NBS genes responded more quickly and strongly in the resistance genotype 'Bukammen' than in the susceptible FDP821 [46].

More interestingly, although $R$ genes manifested different response to the same pathogen with different genetic backgrounds, the $R$ gene might display similar expression pattern after different pathogen infections. Three NBS-LRR genes (gene15578, gene24117 and gene31333) always had up-regulated expression in $F$. vesca after infection both by powdery mildew and P. cactorum. Especially, the gene15587 possessed the highest expression levels with powdery mildew infection and $P$. cactorum infection, suggesting that the same $R$ gene might participate in response to different pathogens, as reported in other plants [48]. For example, Arabidopsis activated disease resistance gene 1 (ADR1) encoding special CCNBS-LRR proteins (CCR-NBS-LRR), participates in host-cell defense responses to Peronospora parasitica and Erysiphe cichoracearum [48].

Furthermore, most of the DEGs were located in the Fragaria lineage-specific duplicated clades in the phylogenetic tree (Additional file 3: Figure S1). Among these DEGs, gene31333, gene04436 and gene00460 had $\mathrm{Ka} / \mathrm{Ks}$ ratios larger than 1 , indicating positive selection acting on these $R$ genes. All of these might provide chances for screening of functional genes or molecular markers related to disease-resistance in strawberry genomes.

\section{Conclusions}

A total of 1134 NBS-LRRs were identified in the six Fragaria species, including 325, 155, 190, 187, 133 and 144 NBS-LRRs in F. $x$ ananassa, F. iinumae, F. nipponica, $F$. nubicola, $F$. orientalis, and $F$. vesca, respectively. Among the NBS-LRR genes, 866 of them could be classified into 184 multi-gene families across the six Fragaria genomes, with highly significantly greater identities in orthologs than those in paralogs. In contrast, the Ks ratios of orthologs were extremely significantly lower than those of paralogs in all NBS-LRR multi-gene families. There were more Fragaria lineagespecific duplicated clades with short branch lengths and shallow nodes than species-specific duplicated clades in the phylogenetic tree. The shared hotspot regions of duplicated NBS-LRRs were detected on the same chromosomes across the six Fragaria species. All of these results suggest lineage-specific duplications of NBS-LRR genes occurred before the divergence of the six Fragaria species. In addition, the TNLs had significantly greater $K s$ and $K a / K s$ ratios than non-TNLs, demonstrating that the TNLs duplicated earlier with more rapid evolutionary rate and under stronger selective pressures than non-TNLs. Furthermore, the expression patterns of NBS-LRR genes indicated that the same $R$-gene showed different expression profiles under different genetic backgrounds in response to pathogens.

\section{Additional files}

Additional file 1: Table S1. Number of NBS-LRR genes in each family among six Fragaria species. (XLSX $16 \mathrm{~kb}$ )

Additional file 2: Table S2. Identities of NBS-LRR genes in TNL and non-TNL gene families. (XLSX $66 \mathrm{~kb}$ )

Additional file 3: Figure S1. Phylogenetic tree of all NBS-LRR genes among six Fragaria species. The red, yellow, purple, light blue, green and blue circles represent genes from $F . x$ ananassa, F.iinumae, F. nipponica, $F$. nubicola, $F$. orientalis and $F$. vesca, respectively. The red circle means lineage-specific duplicated clades and the red rectangle means species-specific duplicated clades. DEG in HW and YW after infection with powdery mildew is marked by yellow highlight; DEG in HW during infection with $P$. cactorum is marked by blue wave line. (PDF 281 kb)

Additional file 4: Figure S2. Species tree of the six Fragaria species. (JPEG $23 \mathrm{~kb}$ )

Additional file 5: Figure S3. The $K s$ ranges of NBS-LRR genes in six Fragaria species. The $K s$ ranges between paralogs (A), orthologs (B) and all genes (C) in TNLs and the Ks ranges between paralogs (D), orthologs (E) and all genes (F) in non-TNLs among the six species. (JPEG $1759 \mathrm{~kb}$ )

\section{Abbreviations}

CDS: Nucleotide coding sequences; NBS-LRR: Nucleotide binding sites-leucinerich repeats; $R$ gene: Resistance gene

\section{Acknowledgments}

Not applicable.

\section{Funding}

This study was supported by the National Natural Science Foundation of China (31501737 and 31570368), partly supported by the open funds of the State Key Laboratory of Crop Genetics and Germplasm Enhancement (ZW201711) and the Fundamental Research Funds for the Central Universities (KUQN201655).

The funders had no role in the design of the study and collection, analysis, and interpretation of data and in writing the manuscript.

Availability of data and materials

The NBS-LRR sequences of the six Fragaria species will be available from the corresponding author on reasonable request.

\section{Authors' contributions}

$Y Z$ and $Z M C$ designed this study. $Y Z$ and $X Z$ performed the data analyses. $Y Z$ drafted the manuscript. $Z Y, X Z$ and $Z M C$ critically revised the manuscript. All authors read and approved the final manuscript, and agreed to be accountable for all aspects of the work.

Ethics approval and consent to participate Not applicable.

\section{Consent for publication}

Not applicable.

\section{Competing interests}

The authors declare that they have no competing interests.

\section{Publisher's Note}

Springer Nature remains neutral with regard to jurisdictional claims in published maps and institutional affiliations. 


\section{Author details}

'College of Horticulture, Nanjing Agricultural University, Nanjing 210095, China. ${ }^{2}$ School of Life Science, Nanjing University, Nanjing 210023, China. ${ }^{3}$ Department of Plant Sciences, University of Tennessee, Knoxville, TN 37996, USA.

Received: 2 November 2017 Accepted: 31 January 2018

Published online: 08 February 2018

\section{References}

1. Dangl $\mathrm{L}$, Jones JD. Plant pathogens and integrated defence responses to infection. Nature. 2001;411(6839):826-33.

2. Jones JD, Dangl JL. The plant immune system. Nature. 2006:444(7117):323-9.

3. McHale L, Tan XP, Koehl P, Michelmore RW. Plant NBS-LRR proteins: adaptable guards. Genome Biol. 2006:7(4):212.

4. Kajava AV. Structural diversity of leucine-rich repeat proteins. J Mol Biol. 1998;277(3):519-27.

5. Chisholm ST, Coaker G, Day B, Staskawicz BJ. Host-microbe interactions: shaping the evolution of the plant immune response. Cell. 2006;124(4):80314.

6. Caplan J, Padmanabhan M, Dinesh-Kumar SP. Plant NB-LRR immune receptors: from recognition to transcriptional reprogramming. Cell Host Microbe. 2008;3(3):126-35.

7. Shen QH, Saijo Y, Mauch S, Biskup C, Bieri S, Keller B, Seki H, Ulker B, Somssich IE, Schulze-Lefert P. Nuclear activity of MLA immune receptors links isolate-specific and basal disease-resistance responses. Science. 2007; 315(5815):1098-103

8. Meyers BC, Dickerman AW, Michelmore RW, Sivaramakrishnan S, Sobral BW, Young ND. Plant disease resistance genes encode members of an ancient and diverse protein family within the nucleotide-binding superfamily. Plant J. 1999;20(3):317-32

9. Shao ZQ, Xue JY, Wu P, Zhang YM, Wu Y, Hang YY, Wang B, Chen JQ. Large-scale analyses of angiosperm nucleotide-binding site-Leucine-rich repeat genes reveal three anciently diverged classes with distinct evolutionary patterns. Plant Physiol. 2016;170(4):2095-109.

10. Bonardi V, Tang SJ, Stallmann A, Roberts M, Cherkis K, Dangl JL. Expanded functions for a family of plant intracellular immune receptors beyond specific recognition of pathogen effectors. P Natl Acad Sci USA. 2011; 108(39):16463-8.

11. Collier SM, Hamel LP, Moffett P. Cell death mediated by the N-terminal domains of a unique and highly conserved class of NB-LRR protein. Mol Plant Microbe In. 2011;24(8):918-31.

12. Xiao SY, Ellwood S, Calis O, Patrick E, Li TX, Coleman M, Turner JG. Broadspectrum mildew resistance in Arabidopsis thaliana mediated by RPW8. Science. 2001;291(5501):118-20.

13. Li Y, Zhong Y, Huang K, Cheng ZM. Genomewide analysis of NBS-encoding genes in kiwi fruit (Actinidia Chinensis). J Genet. 2016;95(4):997-1001.

14. Zhong Y, Yin H, Sargent DJ, Malnoy M, Cheng ZM. Species-specific duplications driving the recent expansion of NBS-LRR genes in five Rosaceae species. BMC Genomics. 2015;16:77.

15. Zhong Y, Li YJ, Huang KH, Cheng ZM. Species-specific duplications of NBSencoding genes in Chinese chestnut (Castanea Mollissima). Sci Rep-Uk. 2015;5:16638

16. Yang SH, Zhang XH, Yue JX, Tian DC, Chen JQ. Recent duplications dominate NBS-encoding gene expansion in two woody species. Mol Gen Genomics. 2008;280(3):187-98.

17. Meyers BC, Kozik A, Griego A, Kuang HH, Michelmore RW. Genome-wide analysis of NBS-LRR-encoding genes in Arabidopsis. Plant Cell. 2003;15(4): 809-34

18. Zhou T, Wang Y, Chen JQ, Araki H, Jing Z, Jiang K, Shen J, Tian D. Genomewide identification of NBS genes in japonica rice reveals significant expansion of divergent non-TIR NBS-LRR genes. Mol Gen Genomics. 2004; 271(4):402-15

19. Chen $\mathrm{QH}$, Han ZX, Jiang HY, Tian DC, Yang SH. Strong positive selection drives rapid diversification of R-genes in Arabidopsis relatives. J Mol Evol. 2010;70(2):137-48

20. Li J, Ding J, Zhang W, Zhang Y, Tang P, Chen JQ, Tian D, Yang S. Unique evolutionary pattern of numbers of gramineous NBS-LRR genes. Mol Gen Genomics. 2010;283(5):427-38.

21. Hummer KE, Nathewet $P$, Yanagi T. Decaploidy in Fragaria iturupensis (Rosaceae). Am J Bot. 2009;96(3):713-6.
22. Staudt G. Strawberry biogeography, genetics and systematics. In: VI International strawberry symposium 842: 2008; 2008. p. 71-84.

23. Darrow GM: The strawberry. History, breeding and physiology. 1966.

24. Tanksley SD, McCouch SR. Seed banks and molecular maps: unlocking genetic potential from the wild. Science. 1997;277(5329):1063-6.

25. Hirakawa H, Shirasawa K, Kosugi S, Tashiro K, Nakayama S, Yamada M, Kohara M, Watanabe A, Kishida Y, Fujishiro T, et al. Dissection of the Octoploid strawberry genome by deep sequencing of the genomes of Fragaria species. DNA Res. 2014;21(2):169-81.

26. Larkin MA, Blackshields G, Brown NP, Chenna R, McGettigan PA, McWilliam H, Valentin F, Wallace IM, Wilm A, Lopez R, et al. Clustal W and clustal X version 2.0. Bioinformatics. 2007;23(21):2947-8.

27. Tamura K, Stecher G, Peterson D, Filipski A, Kumar S. MEGA6: molecular evolutionary genetics analysis version 6.0. Mol Biol Evol. 2013;30(12): 2725-9.

28. Yang ZH. PAML 4: Phylogenetic analysis by maximum likelihood. Mol Biol Evol. 2007:24(8):1586-91.

29. Price MN, Dehal PS, Arkin AP. FastTree 2-approximately maximum-likelihood trees for large alignments. PLoS One. 2010;5(3):e9490.

30. Jambagi S, Dunwell JM. Global Transcriptome analysis and identification of differentially expressed genes after infection of Fragaria Vesca with powdery mildew (Podosphaera aphanis). Transcriptomics. 2015;2:106

31. Toljamo A, Blande D, Karenlampi S, Kokko H. Reprogramming of strawberry (Fragaria Vesca) root Transcriptome in response to Phytophthora Cactorum. PLoS One. 2016;11(8):e0161078.

32. Shao ZQ, Zhang YM, Hang YY, Xue JY, Zhou GC, Wu P, Wu XY, Wu XZ, Wang $Q$, Wang B, et al. Long-term evolution of nucleotide-binding siteLeucine-rich repeat genes: understanding gained from and beyond the legume family. Plant Physiol. 2014;166(1):217-34.

33. Lynch M, Conery JS. The evolutionary fate and consequences of duplicate genes. Science. 2000;290(5494):1151-5.

34. Hurles M. Gene duplication: the genomic trade in spare parts. PLoS Biol. 2004:2(7):900-4

35. Yang $S H$, Feng $Z M$, Zhang $X Y$, Jiang $K$, Jin $X Q$, Hang $Y Y$, Chen JQ, Tian DC Genome-wide investigation on the genetic variations of rice disease resistance genes. Plant Mol Biol. 2006;62(1-2):181-93.

36. Plocik A, Layden J, Kesseli R. Comparative analysis of NBS domain sequences of NBS-LRR disease resistance genes from sunflower, lettuce, and chicory. Mol Phylogenet Evol. 2004;31(1):153-63.

37. Cannon SB, Zhu HY, Baumgarten AM, Spangler R, May G, Cook DR, Young ND. Diversity, distribution, and ancient taxonomic relationships within the TIR and non-TIR NBS-LRR resistance gene subfamilies. J Mol Evol. 2002;54(4): 548-62.

38. Njuguna W, Liston A, Cronn R, Ashman TL, Bassil N. Insights into phylogeny, sex function and age of Fragaria based on whole chloroplast genome sequencing. Mol Phylogenet Evol. 2013;66(1):17-29.

39. Rousseau-Gueutin M, Lerceteau-Kohler E, Barrot L, Sargent DJ, Monfort A, Simpson D, Arus P, Guerin G, Denoyes-Rothan B. Comparative genetic mapping between octoploid and diploid Fragaria species reveals a high level of colinearity between their genomes and the essentially disomic behavior of the cultivated octoploid strawberry. Genetics. 2008;179(4):2045-60.

40. Li WH, Wu Cl, Luo CC. A new method for estimating synonymous and nonsynonymous rates of nucleotide substitution considering the relative likelihood of nucleotide and Codon changes. Mol Biol Evol. 1985:2(2): 150-74

41. Yue JX, Meyers BC, Chen JQ, Tian DC, Yang SH. Tracing the origin and evolutionary history of plant nucleotide-binding site-leucine-rich repeat (NBS-LRR) genes. New Phytol. 2012;193(4):1049-63.

42. Zhu HY, Cannon SB, Young ND, Cook DR. Phylogeny and genomic organization of the TIR and non-TIR NBS-LRR resistance gene family in Medicago truncatula. Mol Plant Microbe Interact. 2002;15(6):529-39.

43. Zhang XH, Feng Y, Cheng H, Tian DC, Yang SH, Chen JQ. Relative evolutionary rates of NBS-encoding genes revealed by soybean segmenta duplication. Mol Gen Genomics. 2011;285(1):79-90

44. Li J, Zhang QY, Gao ZH, Wang F, Duan K, Ye ZW, Gao QH. Genome-wide identification and comparative expression analysis of NBS-LRR-encoding genes upon Colletotrichum gloeosporioides infection in two ecotypes of Fragaria vesca. Gene. 2013;527(1):215-27.

45. Casado-Diaz A, Encinas-Villarejo S, de los Santos B, Schiliro E, YuberoSerrano EM, Amil-Ruiz F, Pocovi MI, Pliego-Alfaro F, Dorado G, Rey M, et al. 
Analysis of strawberry genes differentially expressed in response to Colletotrichum infection. Physiol Plantarum. 2006;128(4):633-50.

46. Chen XR, Brurberg MB, Elameen A, Klemsdal SS, Martinussen I. Expression of resistance gene analogs in woodland strawberry (Fragaria vesca) during infection with Phytophthora cactorum. Mol Gen Genomics. 2016;291(5): 1967-78.

47. Zhang QY, Zhang LQ, Song LL, Duan K, Li N, Wang YX, Gao QH. The different interactions of Colletotrichum gloeosporioides with two strawberry varieties and the involvement of salicylic acid. Hortic Res. 2016;3:16007.

48. Grant JJ, Chini A, Basu D, Loake GJ. Targeted activation tagging of the Arabidopsis NBS-LRR gene, ADR1, conveys resistance to virulent pathogens. Mol Plant Microbe Interact. 2003;16(8):669-80.

Submit your next manuscript to BioMed Central and we will help you at every step:

- We accept pre-submission inquiries

- Our selector tool helps you to find the most relevant journal

- We provide round the clock customer support

- Convenient online submission

- Thorough peer review

- Inclusion in PubMed and all major indexing services

- Maximum visibility for your research

Submit your manuscript at www.biomedcentral.com/submit 